\title{
GC-MS and HPLC-ESI-MS-MS Characterization of Sanchezia oblonga (Acanthaceae) Extracts
}

\author{
Juliana Mourão Ravasi ${ }^{1}$, Giuseppina $\mathrm{Negri}^{2}$, Antonio Salatino ${ }^{2}$, Maria Luiza Faria Salatino ${ }^{2} \&$ Marco Aurelio \\ Sivero Mayworm ${ }^{1}$ \\ ${ }^{1}$ Curso de Ciências Biológicas, Universidade Santo Amaro (UNISA), 04829-300, São Paulo, SP, Brazil \\ ${ }^{2}$ Instituto de Biociências, Universidade de São Paulo, 05508-090, São Paulo, SP, Brazil \\ Correspondence: Giuseppina Negri, Laboratory of Phytochemistry, Department of Botany, Institute of \\ Biosciences, University of São Paulo, Rua do Matão 277 sala 154, CEP 05508-090, São Paulo SP, Brazil. E-mail: \\ gnegri@terra.com.br
}

Received: November 13, 2019

Accepted: December 15, 2019 Online Published: January 22, 2020

doi:10.5539/jfr.v9n1p57

URL: https://doi.org/10.5539/jfr.v9n1p57

\begin{abstract}
The genus Sanchezia (Acanthaceae) comprises neotropical herbs and shrubs with showy flowers. Sanchezia oblonga (syn. S. nobilis) is a shrub of the rainforests of central and south America. The ethanolic extracts of leaves and stems from S. oblonga were analyzed by GC-EI-MS and RPHPLC-DAD-ESI-MS/MS. Fatty acids (free and esterified) and phytosterols were detected by the former method. Benzyl alcohol glycosides (21 and 25), sinapic acid glycoside esters (29 and 31), ethyl rosmarinate (24), sinapic acid-O-glucoside (28), dihydrosinapic acid-O-glucoside (26), catechin-O-arabinoside (36), in addition to flavonols glycosides (23, 32, 33 and 35) and rosmarinic acid-3'-O-glucoside (34) were detected by RPHPLC-DAD-ESI-MS/MS. Three new compounds, detected only in leaves, were tentatively identified as phenylpropane glyceride derivatives 1-O-coumaroyl-2-hydroxy propanal (20) and 1-O-coumaroyl-2- $O$-glycosyl propanal $(22,30)$. Compounds 20,22 and 30 from S. oblonga are similar with phenylpropane glycerides present in red sorghum (Sorghum bicolor L. (Moench) and Lilium longiflorum Thunb. It is noteworthy that S. oblonga could be used in cooking as a complement after more detailed studies. Sorghum grain foods exhibit potential health benefits against chronic diseases related to over-nutrition. Lilium longiflorum possess flower buds and bulbs that are used for both culinary and medicinal purposes in many parts of the world. Studies on chemical composition and biological activity of the genus Sanchezia are scarce. The presence of phytosterols and flavonol glycosides were recently reported in leaves from this species. However, the chemical profile of the extracts analyzed in this work differs from that previously reported for aerial parts of $S$. nobilis ( $\sin$. S. oblonga). Further studies, including statistical methods, such as principal component analysis and hierarchical cluster analysis will be needed to evaluate chemical markers for this species.
\end{abstract}

Keywords: Sanchezia oblonga, Acanthaceae, sinapic acid ester glycosides, phenylpropane glycerides, phytosterols

\section{Introduction}

Species of Sanchezia Ruiz \& Pav. (Acanthaceae) are neotropical herbs and shrubs. Several species of Sanchezia, such as S. parvibracteata, S. nobilis and S. speciosa, are cultivated as ornamentals in tropical areas and botanical gardens due to their showy leaves and conspicuous bright and colorful flowers. Recently, this genus was revised by Leonard and Smith (1964); among 58 species, over half were newly described (Tripp and Koenemann, 2015). There are few reports on chemical constituents and pharmacological activity of Sanchezia species. Therefore, there is no exhaustive identification of the basic chemical constituents and comprehensive quality control of this genus. S. speciosa contains cardiac and flavonoid glycosides and their extracts exhibited antioxidant and anti-inflammatory activities (Bui Thanh et al., 2017). Extracts of the same species exerted cytotoxicity in human epithelial cervical cancer cell lines (Shaheen et al., 2017, Parvin et al., 2015).

Sanchezia oblonga Ruiz \& Pav. (syn. Sanchezia nobilis Hook. f.) is a perennial evergreen shrub from the rainforests of Central and South America (Ellah et al. 2013, 2014). An earlier study reported that S. nobilis extracts contain syringin, flavone glycosides, cinnamyl and benzyl alcohol glycosides, neolignan glucoside, besides matsutake alcohol glycosides (Ellah et al. 2013, 2014). The presence of the phytosterols daucosterol 
and stigmasterol, flavonol glycosides, scopoletin and 3'-O-methyl-3,4- methylenedioxy ellagic acid in ethylacetate extract of the leaves of S. nobilis was reported recently (Xuan et al., 2019a, Loi et al., 2019a). On the other hand, mangiferin, $\beta$-sitosterol, in addition to margaric, ursolic and oleanolic acids were isolated from $n$-hexane extracts (Xuan et al., 2019b), while 4',5,7-trihydroxy-3',5'-dimethoxyflavone and kaempferol glycosides were isolated from aqueous extracts of leaves (Loi et al., 2019b).

In this study, the ethanolic extracts of $S$. oblonga leaves and stems were analyzed by GC-EI-MS and RPHPLC-ESI-MS / MS. Phenylpropane glycerides similar with thoses found in red sorghum (Sorghum bicolor L. (Moench) and and Lilium longiflorum Thunb. were detected only in ethanolic extracts of leaves, while flavonol glycosides and phytosterols were detected only in ethanolic extracts of stems.

\section{Material and Methods}

\subsection{Plants Material}

S. oblonga leaves and stems were collected from plants growing on the campus I of Santo Amaro University (UNISA), São Paulo, State of São Paulo (southeast Brazil). A voucher sample was deposited at the Santo Amaro University Herbarium (UNISA 4121). The leaves and stems were washed and cleaned prior to air drying at room temperature for one week. The dried and powdered leaf and stem material ( $2 \mathrm{~g}$ each) was macerated separately for 30 days in a $500 \mathrm{ml}$ conical flask containing $200 \mathrm{~mL}$ of high quality ethanol (Sigma Chemical Co). The solvent was replaced weekly during extraction at room temperature and protected from light. The extracts were filtered first through cotton and then through Whatman paper \# 1 and then concentrated in rotary evaporator (Büchi, Switzerland). Leaves and stems provided $130 \mathrm{mg}$ and $90 \mathrm{mg}$, respectively of dried extracts, which were stored in amber flasks at $5^{\circ} \mathrm{C}$.

\subsection{Analyses of the Leac Extract by Fourier Transform Infrared Spectrometry (FT-IR)}

Only the ethanolic extract from leaves was analyzed by FT-IR. Several drops of the extract from leaves were placed onto a $\mathrm{KBr}$ aperture plate and sandwiched under another aperture plate such that no gas bubbles were trapped. The FT-IR spectrum was obtained using a Frontier PerkinElmer spectrometer equipped with a $\mathrm{KBr}$ beam splitter. The spectra were recorded at room temperature from an average of 32 scans in the range 4000-400 $\mathrm{cm}^{-1}$, with $5 \mathrm{~cm}^{-1}$ spectrum resolution, normalization at $1030 \mathrm{~cm}^{-1}$ and aperture of $5.0 \mathrm{~mm}$. The influences of $\mathrm{H}_{2} \mathrm{O}$ and $\mathrm{CO}_{2}$ were subtracted automatically by the software operating the spectrometer.

\subsection{GC/EIMS Analyses of Ethanolic Extracts from Leaves and Stems}

Crude extracts from leaves and stems $(5 \mathrm{mg}$ ) were dissolved in $1 \mathrm{~mL}$ of high grade ethanol supplied (Sigma Chemical Co). An aliquot of $1 \mu \mathrm{L}$ of each extract was analyzed using a Shimadzu GCMS-QP505A gas chromatograph equipped with a ZB-5ms fused silica capillary column BPX5 (5\% phenyl arylene/95\% dimethylpolysiloxane, $30 \mathrm{~m} \times 0.25 \mathrm{~mm}$ internal diameter $\mathrm{x} 0.25 \mu \mathrm{m}$ film thickness) coupled to an ion-trap mass detector. Mass spectra were acquired in the electron-impact (EI) mode with an ionization voltage of $70 \mathrm{eV}$. The GC conditions were set as follows: the oven was programmed with an initial temperature of $100{ }^{\circ} \mathrm{C}$, maintained for $5 \mathrm{~min}$ and then increased to $320^{\circ} \mathrm{C}$ at a rate of $6{ }^{\circ} \mathrm{C} / \mathrm{min}$. The final temperature was maintained for $10 \mathrm{~min}$. The air and hydrogen flow rates were $400 \mathrm{~mL} / \mathrm{min}$ and $29.5 \mathrm{~mL} / \mathrm{min}$, respectively. Helium was used as the carrier gas at a flow rate of $2.1 \mathrm{~mL} / \mathrm{min}$, linear velocity of $53.8 \mathrm{~cm} / \mathrm{sec}$, column pressure of $150.0 \mathrm{KPa}$ and total flow of $29.5 \mathrm{~mL} / \mathrm{min}$. The MS conditions were set as follows: filament current $0.3 \mathrm{~mA}$; detector voltage $-0.7 \mathrm{kV}$, ion source temperature $300{ }^{\circ} \mathrm{C}$; interface temperature, $300{ }^{\circ} \mathrm{C}$; split ratio of 11 and scan speed of 2 scans s ${ }^{-1}$. The mass range was 120-700 Da over 52 min (full scan mode) (Negri et al., 2018).

Fragmentation patterns of the EI mass spectra of compounds were compared via spectrum matching with reference mass spectra of libraries NIST 21, Wiley 275 and Wiley 229 (Hewlett Packard, Wiley/NBS) (Koo et al. 2013). The identification of constituents was based on the best mass spectrum (MS) matching score (NIST Mass Spectrum number was added in Table 1) and MS data published in literature. Relative content was estimated by integration of the areas under the corresponding chromatogram peaks.

\subsection{RPHPLC-SPD-ESI-MS/MS Analyses of Ethanolic Extracts from Leaves and Stems}

HPLC grade methanol was purchased from Merck (Darmstadt, Germany). HPLC grade water was prepared with distilled water using a Milli-Q system (Millipore, Waters, Milford, MA, USA). The ethanolic extracts of leaves and stems (5 mg dissolved in $2 \mathrm{ml}$ of methanol $-2.5 \mathrm{mg} / \mathrm{mL}$ ) were filtered through $0.45 \mu \mathrm{m}$ polytetrafluoroethylene (PTFE) membrane filters, before a $30 \mu \mathrm{L}$ aliquot was injected into the HPLC system (Coelho et al., 2018). The RPHPLC-SPD-ESI-MS/MS analysis were conducted using an SPD-M10AVP Shimadzu system equipped with a photodiode array detector coupled to an Esquire 3000 Plus Mass Spectrometry system (Bruke Daltonics, Billerica, MA, USA), coupled with two LC-20AD pumps, SPD-20A diode array 
detector, CTO-20A column oven and SIL 20AC autosampler (Shimadzu Corporation Kyoto, Japan). All the operations, acquisitions and data analyses were controlled by the Shimadzu CBM-20A software. Separations were carried out using a C18 RP Luna Phenomenex reverse phase column (4.6 x $250 \mathrm{~mm}$ i.d., $5 \mu \mathrm{m}$ of particle size) protected with a security guard cartridge (Gemini C18, $4.0 \times 2.0 \mathrm{~mm}$ i.d.). The mass spectrometer was an ion trap with atmospheric pressure ionization method through electrospray ionization interface (ESI) operating in the scan MS mode from $\mathrm{m} / \mathrm{z} 100$ to 1500 . The mobile phase was composed of eluent $\mathrm{A}(0.1 \%$ aq. formic acid) and eluent $\mathrm{B}$ (methanol) at the constant flow rate $1.0 \mathrm{~mL} \mathrm{~min}^{-1}$ and constant temperature of the column oven at $40{ }^{\circ} \mathrm{C}$. The following elution program, based on concentrations of the B solvent, was used: $0 \mathrm{~min}, 20 \%$; $10 \mathrm{~min}$, $40 \%$; $20 \mathrm{~min}, 60 \%$; $30 \mathrm{~min}, 80 \%$; $40 \mathrm{~min}, 100 \%$; $50 \mathrm{~min}, 20 \%$. The time for the whole run was $60 \mathrm{~min}, 10$ minutes were needed for equilibration of the column. Helium was used as the collision and nitrogen as the nebulizing gas, respectively. Nebulization was aided with a coaxial nitrogen sheath gas provided at pressure of $27 \mathrm{psi}$. Mass spectra were acquired in negative mode with ion spray voltage at $3.0 \mathrm{kV}$, capillary temperature at $300^{\circ} \mathrm{C}$, capillary voltage at $45 \mathrm{~V}$ and drying gas flow $6 \mathrm{~L} / \mathrm{min}$. Collision induced dissociation spectra were obtained in the ion trap using helium as the collision gas, with voltage ramping cycles from 0.5 to $1.3 \mathrm{~V}$. Data were analyzed by an HP Chemistation System and Bruker Daltonics Data Analysis.

The analytes were characterized by their respective ultraviolet and mass spectra, which were compared with literature data and the mass spectra database Phenol-Explorer (www.phenol-explorer.eu), ChemSpider (http: //www.chemspider. com), Metlin (http://metlin.scripps.edu) and HMDB (www.hmdb.ca).

\section{Results}

\subsection{Analyses of the Leaf Extract by Fourier Transform Infrared Spectrometry (FT-IR)}

Fourier transform infrared spectrometry is used for analysis, because it represents a non-invasive analytical tool allowing a fast and simultaneous qualitative and quantitative characterization of natural products and their constituents. The infrared (IR) spectrum of the ethanolic extract of leaves exhibited bands at 3369, 3012, 2925, $2854,1737,1640,1454,1409,1378,1346,1240,1162$ and $1073 \mathrm{~cm}^{-1}$. The maximum absorptions were attributed to the following functional groups: at $3369-3200 \mathrm{~cm}^{-1}$ (stretching of free $\mathrm{OH}$, as sharp peak), 2925 $2854 \mathrm{~cm}^{-1}$ (C-H aliphatic stretching), $1737 \mathrm{~cm}^{-1}$ ( $\mathrm{C}=\mathrm{O}$ ester bond) and $1640 \mathrm{~cm}^{-1}$ ( $\mathrm{C}=\mathrm{C}$ aromatic). The $\mathrm{C}-\mathrm{O}$ stretching characteristic from esters appeared in the region $1346-1240 \mathrm{~cm}^{-1}$. The peak at $1737 \mathrm{~cm}^{-1}$ assigned to the $\mathrm{C}=\mathrm{O}$ stretching vibration means that some carbonyl compounds exist in the leaves of S. Oblonga. Bands from 1240 to 1162 were attributed to $\mathrm{C}-\mathrm{O}$ stretching of phenolics and asymmetric C-C-O stretching of esters. The bands between 1454- $1409 \mathrm{~cm}^{-1}$ are attributed to the asymmetric in-plane bending of $-\mathrm{CH}_{3}$, which is also the same spectral region reflecting to the phenyl $(\mathrm{C}=\mathrm{C}$ bonds). The absorption bands that were attributed to $\mathrm{C}=\mathrm{C}$ stretching vibration at $1640 \mathrm{~cm}-1$ and the band at $1378 \mathrm{~cm}-1$ referred to C-O stretching vibration of phenyl groups were observed indicating the presence of phenolic compounds. FT-IR analysis results revealed the presence of fatty acids and its respective ethyl esters and phenolic compounds, such as phenylpropane glycerides.

\subsection{Compounds Detected In Leaves and Stems by GC-EI-MS Analysis}

The extraction of phenolic compounds depends mainly on the nature of the sample matrix and its chemical properties including molecular structure, polarity of solvent, concentration, number of aromatic rings and hydroxyl groups. Identification of compounds 1-18 (Table 1) was performed by mass spectra through molecular ions $\mathrm{M}^{+} \cdot{ }^{\cdot}$ and fragmentation patterns, which were compared with NIST 21 and Wiley-275 libraries. For compounds $1-18$, the similarity percentages obtained are equal to or greater than $95 \%$ with the NIST Match Factor - 850.6. Mass spectral data from the literature has also been used to identify fatty acids $(4,7,10$ and 11) (Hong and Kim, 2013) and their ethyl esters (5, 9 and 12) (Monção et al., 2015, Sudha et al., 2013), phytosterols (14-18) (Chen et al., 2015, Suttiarporn et al., 2015), squalene (13), butanoic acid butyl ester (1) (Oliveira-Garcia et al., 2015), methyl salicylate (2) (Jayasekara et al., 2002), 5-methyl-4-hepten-3-one (3), 9,12-octadecadienal (8) (Hong et al., 2013) and phytol (6) (Sudha et al., 2013). High content of 5-methyl-4-hepten-3-one (3) was detected in both extracts. Phytosterols 14-18 were not detected in the ethanolic extract of the leaves. Figure 1 shows the GC-EI-MS mass spectrum of ethyl palmitate (5), stigmasterol (15) and sitosterol (16). 
Table 1. Compounds 1- 18 detected in the analysis of ethanol extract of stems and leaves of Sanchezia oblonga by GC-IE-MS, identified through NIST Mass Spectra and MS data from literature (see text)

\begin{tabular}{|c|c|c|c|c|c|c|}
\hline Cp.N* & $\begin{array}{l}\mathbf{R t}^{* * *}(\mathbf{m} \\
\text { in) }\end{array}$ & $\begin{array}{l}\operatorname{EIMS}\left[\mathrm{M}^{+}\right] \mathrm{m} / z \\
(\%)\end{array}$ & EIMS - Fragments $m / z(\%)$ & $\begin{array}{l}\text { Identification and } \\
\text { (NIST Mass Spectrum number) }\end{array}$ & $\begin{array}{l}\text { Stems } \\
(\%)\end{array}$ & $\begin{array}{l}\text { Leaves } \\
(\%)\end{array}$ \\
\hline 1 & 4.6 & $144(34)$ & $101(40), 89(70), 71(100)$ & butanoic acid butyl ester (228835) & 2.8 & 1.5 \\
\hline 2 & 5.6 & $152(50)$ & $121(25), 120(100), 92(60)$ & methyl salicylate (291552) & 1.1 & - \\
\hline 3 & 6.8 & $126(50)$ & $97(100), 69(50)$ & 5-methyl-4-hepten-3-one (63310) & 31.1 & 21.4 \\
\hline 4 & 24.3 & $256(11)$ & $\begin{array}{l}213(13), 157(14), 129(32), \\
115(14), 83(40), 73(100)\end{array}$ & palmitic acid (151973) & 5.4 & 7.3 \\
\hline 5 & 24.8 & $284(5)$ & $\begin{array}{l}241(7), 157(15), 101(60), 88 \\
(100)\end{array}$ & ethyl palmitate (233204) & 3.7 & 4.7 \\
\hline 6 & 27.0 & $296(1)$ & $\begin{array}{l}123(40), 111(40), 95(50), 81 \\
(60), 71(100)\end{array}$ & phytol (375015) & 1.9 & 41.5 \\
\hline 7 & 27.4 & $280(4)$ & $\begin{array}{l}124(10), 110(17), 95(57), 81 \\
(75), 67(100)\end{array}$ & linoleic acid (229327) & 8.2 & 1.5 \\
\hline 8 & 27.8 & $264(4)$ & $\begin{array}{l}165(2), 108(30), 95(50), 79 \\
(60), 67(70)\end{array}$ & 9,12-octadecadienal (35820) & 7.0 & - \\
\hline 9 & 28.0 & $308(3)$ & $\begin{array}{l}262(6), 153(15), 135(14), \\
109(23), 107(10), 95(59), 81 \\
(81), 67(100)\end{array}$ & ethyl linoleate (155747) & 5.5 & 2.7 \\
\hline 10 & 28.4 & $282(1)$ & $\begin{array}{l}264(7), 222(20), 180(30), \\
135(12), 121(16), 108(24), \\
101(27), 95(53), 69(100)\end{array}$ & oleic acid (134027) & 4.5 & 8.5 \\
\hline 11 & 28.7 & $284(10)$ & $\begin{array}{l}241(30), 185(40), 129(60) \text {, } \\
73(100) \text {. }\end{array}$ & stearic acid (290961) & 1.0 & - \\
\hline 12 & 30.2 & $312(8)$ & $157(13), 101(50), 88(100)$ & ethyl octadecanoate (23294) & 0.6 & - \\
\hline 13 & 38.7 & $410(1)$ & $\begin{array}{l}149(30), 136(30), 121(30), \\
109(30), 95(30), 81(63), 69 \\
(100)\end{array}$ & squalene (227620) & 0.5 & 3.1 \\
\hline 14 & 44.3 & $400(21)$ & $\begin{array}{l}382(30), 367(10), 315(22), \\
289(22), 255(15), 213(57), \\
145(50), 107(60), 95(70)\end{array}$ & campesterol (151556) & 1.3 & - \\
\hline 15 & 44.6 & $412(24)$ & $\begin{array}{l}397(3), 394(3), 369(5), 351 \\
(20), 300(30), 271(19), 255 \\
(20), 159(40), 145(30), 133 \\
(60)\end{array}$ & stigmasterol (352610) & 5.8 & - \\
\hline 16 & 45.4 & $414(35)$ & $\begin{array}{l}399 \text { (18), } 396 \text { (19), } 381 \text { (21), } \\
329 \text { (33), } 303 \text { (17), } 273 \text { (13), } \\
255 \text { (22), } 213 \text { (39), } 207 \text { (41), } \\
173 \text { (21), } 161 \text { (36), } 147 \text { (28), } \\
133 \text { (32) }\end{array}$ & sitosterol (251915) & 4.8 & - \\
\hline 17 & 46.2 & $410(12)$ & $\begin{array}{l}367(33), 298(23), 271(20), \\
245(20), 191(17), 147 \text { (23), } \\
133(27), 119(15)\end{array}$ & stigmasta-4,22-dien-3-one (255385) & 0.6 & - \\
\hline 18 & 47.0 & $412(30)$ & $\begin{array}{l}398(20), 370(30), 289(50), \\
229(40), 149(40), 135(25), \\
124(100), 107(22)\end{array}$ & stigmast-4-en-3-one (17165) & 0.9 & - \\
\hline
\end{tabular}

\footnotetext{
${ }^{*}$ Cp.N: compound number. $* *$ Rt: retention time.
} 


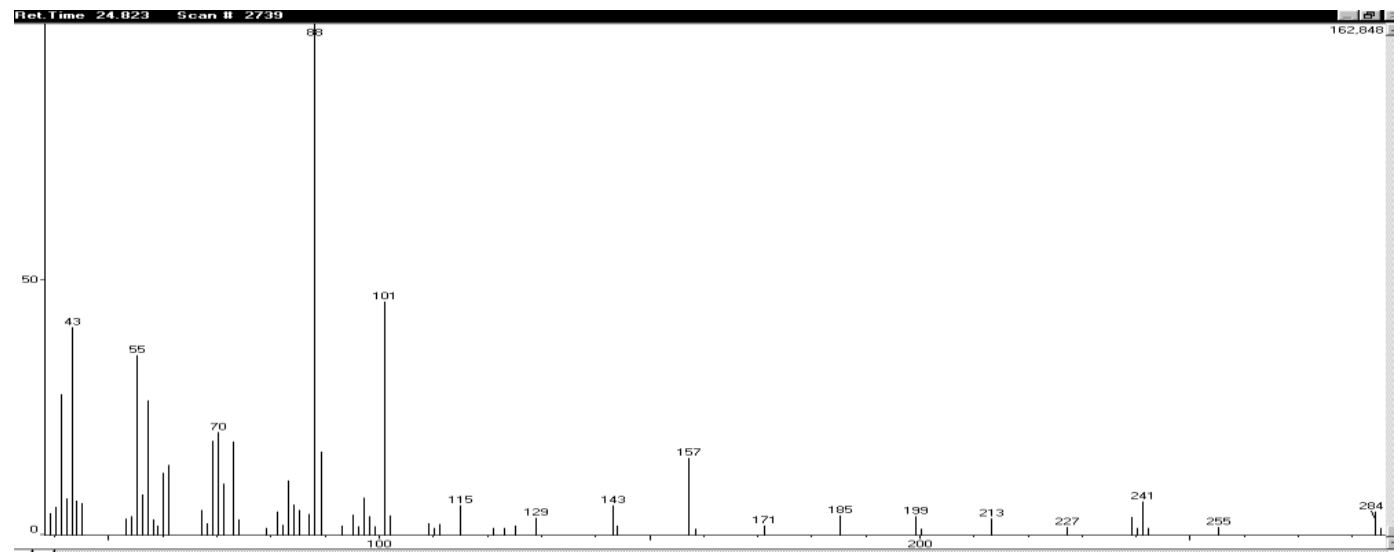

GC-EI-MS mass spectrum of ethyl palmitate (5)

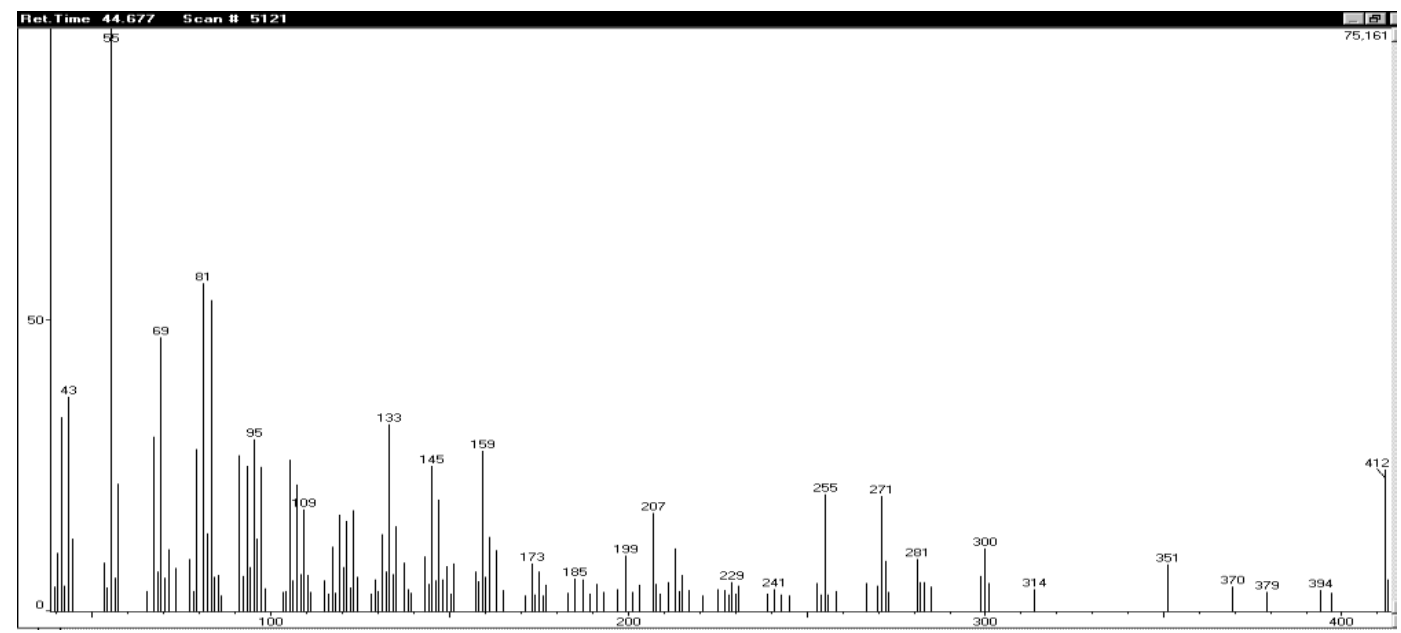

GC-EI-MS mass spectrum of stigmasterol (15)

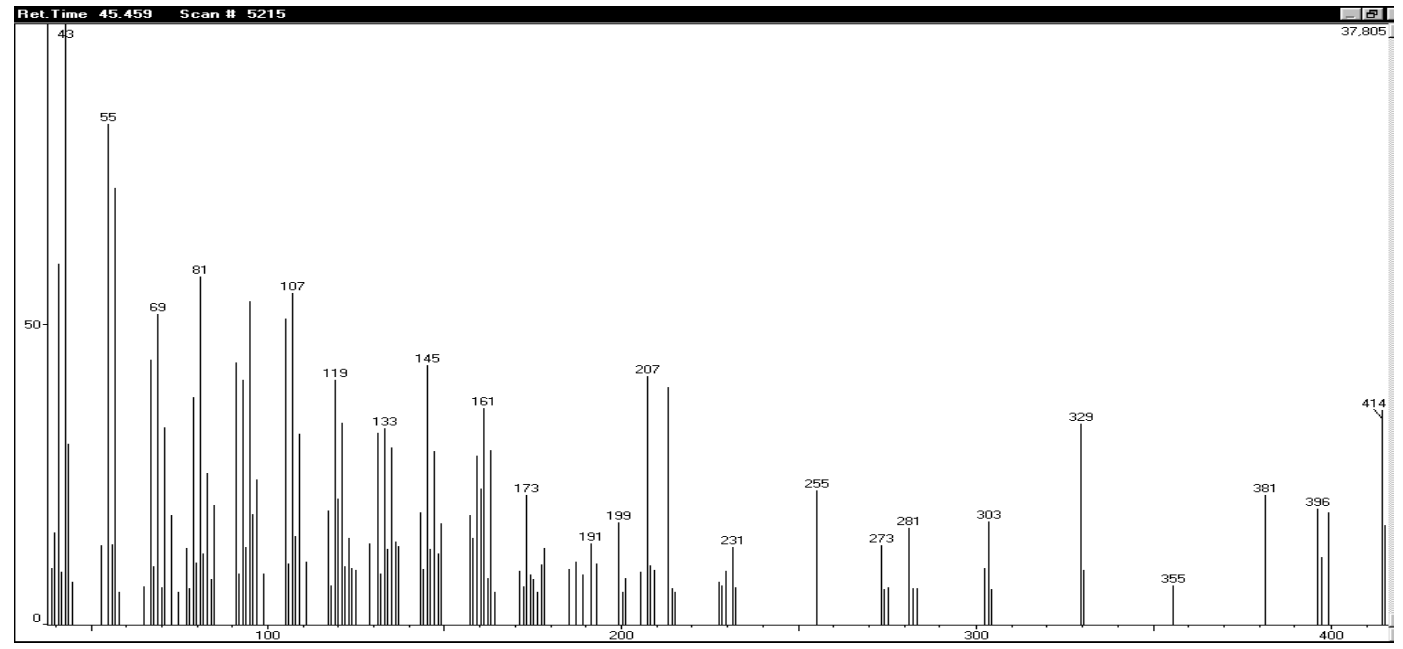

GC-EI-MS mass spectrum of sitosterol (16)

Figure 1. GC-EI-MS mass spectra of compounds 5, 15, 16

\subsection{Compounds Detected in Leaves and Stems by RPHPLC-ESI-MS/MS Analyses}

The identification of compounds 19-36 (Table 2) was based on the MS data in negative ionization mode conjugated with the UV-DAD, which were compared with literature data. In negative ion mode, high abundances of quasi-molecular ions [M-H] $]^{-}$and $[\mathrm{M}-\mathrm{H}+\mathrm{HCOOH}]^{-}$were exhibited by compounds 19-36. (Falção et al., 2013). The glycosyl and alkyl residues are weak chromophores, so these substituents did not change significantly, the 
maximum absorption coefficients and absorption wavelengths of compounds 19, 21-23 and 25-36 (Table 2), indicating that the loss of 132, 146, 162 and $176 \mathrm{Da}$, in these compounds corresponds to arabinose, rhamnose, glucose and glucuronide, respectively.

\subsection{Compounds Detected by RPHPLC-ESI-MS/MS Analyses of Leaf Ethanolic Extract}

Compounds 20, 22, 29, 30, 31, 35 and 36 were detected only in ethanolic extract from leaves (Table 2). Compounds 20, 22 and 30 are new and their identification was based on UV and mass spectra, which were compared with that phenylpropane glycerides isolated from sorghum grain (Kang et al., 2016, Kadam et al., 2018; Nguyen et al., 2015, and Svensson et al., 2010) and Lilium longiflorum Thunb. (Munafo Jr and Gianfagna, 2015). Sorghum is the fifth most-produced cereal in the world and the major producers are USA, Mexico, Nigeria, Sudan and India. Sorghum grain foods is used in many parts of Africa, Asia and the semi-arid tropics world-wide and exhibited potential health benefits against chronic diseases related to over-nutrition. Compound 20 (Rt - $3.6 \mathrm{~min}$ ) exhibited UV maximum absorption at $310 \mathrm{~nm}$, characteristic of coumaric acid derivatives. Their mass spectra exhibited [M - H]- ion at $\mathrm{m} / \mathrm{z} 235$, base peak at $\mathrm{m} / \mathrm{z} 217$ and fragment ion at $\mathrm{m} / \mathrm{z} 199$, both resulting from water loss $(18 \mathrm{Da}$ ). The fragment ion at $\mathrm{m} / \mathrm{z} 155$ was formed by the loss of carbon dioxide (44 Da) from fragment ion at $\mathrm{m} / \mathrm{z} 199$. Compound 20 was tentatively identified as 1-O-coumaroyl-2-hydroxy propanal. Compounds 22 (Rt - $8.3 \mathrm{~min}$ ) and 30 (Rt - $13.3 \mathrm{~min}$ ) displayed the same fragmentation pattern with a base peak at $\mathrm{m} / \mathrm{z} 235$ and were characterized as 1-O-coumaroyl-2-hydroxy propanal derivatives. Compound 22 exhibited $[\mathrm{M}-\mathrm{H}+\mathrm{HCOOH}]-$ adduct ion at $\mathrm{m} / \mathrm{z} 413,[\mathrm{M}-\mathrm{H}]-$ ion at $\mathrm{m} / \mathrm{z} 367$ and the base peak at $\mathrm{m} / \mathrm{z} 235[\mathrm{M}-\mathrm{H}-$ 132]-, was produced by loss of arabinose (132 Da). Based on literature data (Kang et al., 2016, Kadam et al., 2018; Nguyen et al., 2015, Munafo Jr and Gianfagna, 2015; and Svensson et al., 2010), compound 22 was tentatively identified as $1-O$-coumaroyl-2- $O$-arabinosyl propanal. Compound 30 exhibited $[\mathrm{M}-\mathrm{H}+\mathrm{HCOOH}]-$ adduct ion at $\mathrm{m} / \mathrm{z} 427,[\mathrm{M}-\mathrm{H}]-$ at $\mathrm{m} / \mathrm{z} 381$ and the base peak at $\mathrm{m} / \mathrm{z} 235([\mathrm{M}-\mathrm{H}-146]-$, was produced by loss of rhamnose (146 Da). Based on literature data, (Kang et al., 2016; Kadam et al., 2018; Nguyen et al., 2015; Munafo Jr and Gianfagna, 2015; and Svensson et al., 2010), compound 30 was tentatively identified as 1-O-coumaroyl-2-O-rhamnosyl propanal.

p-Coumaroylglycolic acid was reported for Lepidium sativum (Kadam et al., 2018). Caffeoylglycolic acid methyl ester was isolated from the grains of Sorghum bicolor (L.) Moench var. hwanggeumchal Kang et al., 2016; Nguyen et al., 2015). 2-O-coumaroylglycerol and 1-O-coumaroyl-2- $O$-glucosylglycerol were detected in hydromethanolic extracts (50:50) of brown, red and white sorghum whole grains (Kang et al., 2016; and Svensson et al., 2010). Feruloyl-caffeoylglycerol was found in Ananas comosus L. leaves and sorghum grain (Wu et al., 2016). Sorghum grains in the diet promoted cardiovascular health and exhibited beneficial effects for weight control (Kang et al., 2016). Caffeoylglycolic acid methyl ester and 1-O-caffeoylglycerol isolated from Sorghum bicolor, showed inhibitory potential on nitric oxide production (Salazar-López et al., 2018). Lilium longiflorum, an attractive ornamental plant, possesses flower buds and bulbs that are used for both culinary and medicinal purposes in many parts of the world. This species contains significant amounts of phenylpropanoid glycerol glucosides, which may contribute to plant pathogen defense, ultraviolet/high-intensity visible light (UV/high light) protection, and use in traditional medicine (Munafo Jr and Gianfagna, 2015).

Compound 29 (Rt - $12.8 \mathrm{~min}$ ) exhibited UV maximum absorption at $318 \mathrm{~nm}$, characteristic of cinnamic acid derivatives. Its mass spectrum exhibited $[\mathrm{M}-\mathrm{H}+\mathrm{HCOOH}]-$ adduct ion at $\mathrm{m} / z 491,[\mathrm{M}-\mathrm{H}]-$ at $\mathrm{m} / z, \mathrm{z} 11$ and base peak at $\mathrm{m} / \mathrm{z} 279$ (deprotonated butyl sinapate), produced by the loss of arabinose (132 Da). Based on literature data (Teixeira et al., 2013; Nićiforović et al., 2017; Martinović et al., 2019), compound 29 was tentatively identified as 4- $O$-arabinosyl butyl sinapate. For compound 31 (Rt - $13.5 \mathrm{~min}$ ) the mass spectrum exhibited $[\mathrm{M}-\mathrm{H}+\mathrm{HCOOH}]-$ adduct ion at $\mathrm{m} / \mathrm{z} 461$ and $[\mathrm{M}-\mathrm{H}]-$ at $\mathrm{m} / \mathrm{z} 415$. Based on literature data (Teixeira et al., 2013; Nićiforović et al., 2017; Martinović et al., 2019), compound 31 was tentatively identified as 4-O-glucosyl ethyl dihydrosinapate.

Compound 35 (25.1 min) exhibited UV maximum absorption at 266 and $355 \mathrm{~nm}$, characteristic of flavonol. Band I $(330-380 \mathrm{~nm})$ is attributed to the B-ring cinnamoyl system, and Band II $(240-280 \mathrm{~nm})$ is attributed to the A-ring benzoyl system. Mass spectrum of 35 exhibited $[\mathrm{M}-\mathrm{H}+\mathrm{HCOOH}]-$ adduct ion at $\mathrm{m} / \mathrm{z} 493$ and $[\mathrm{M}$ $\mathrm{H}$ ]- ion at $\mathrm{m} / \mathrm{z}$ 447. Based on UV and MS data compared with literature (Soares et al., 2019; Vukics et al., 2010; Pitura and Arntfield, 2019, Loi et al., 2019), compound 35 was identified as kaempferol-3- $O$-glucoside. Compound 36 (Rt - 26.5) exhibited UV maximum absorption at $280 \mathrm{~nm}$ and the mass spectrum gave [M - H]- at $\mathrm{m} / \mathrm{z}$ 421. Its MS/MS fragmentation yielded base peak at $\mathrm{m} / \mathrm{z} 289$ (deprotonated catechin), produced by the loss of arabinose (132 Da). Based on literature data (Kang et al., 2016; Zerbib et al., 2018; Karar and Kuhnert, 2015), compound 36 was tentatively identified as catechin arabinoside. 


\subsection{Compounds detected by RPHPLC-ESI-MS/MS Analyses of Stem Ethanolic Extract}

Compounds 21, 23, 24, 26, 32, 33 and 34 were detected only in ethanolic extract from stems (Table 2). Compound 21 (Rt - $6.1 \mathrm{~min}$, Table 2) exhibited UV maximum absorption at $254 \mathrm{~nm}$. Mass spectrum exhibited $[\mathrm{M}-\mathrm{H}]^{-}$at $\mathrm{m} / \mathrm{z}, 315$ and base peak at $\mathrm{m} / \mathrm{z} 153$ ([M $\left.-\mathrm{H}-162\right]^{-}$, corresponding to the loss of glucose moiety. Compound 21 was identified as 4-hydroxy-3-methoxybenzyl alcohol glucoside, based on literature data (Karar and Kuhnert, 2015; Kumar, 2017; Veličković et al., 2012). The mass spectra of compounds 24 (Rt - 10.3 min) and $26(\mathrm{Rt}-11.0 \mathrm{~min})$ displayed the same $[\mathrm{M}-\mathrm{H}]^{-}$at $\mathrm{m} / \mathrm{z}$ 387. The mass spectrum of compound 24 (Rt - 10.3 min) exhibited base peak at $\mathrm{m} / \mathrm{z}, 163$, that resulted to the loss of $225 \mathrm{Da}$ from the molecular ion at $\mathrm{m} / \mathrm{z}$ 387, which was formed by cleavage of the ester bond (Aziz et al., 2014; Shen et al., 2018; Wicha et al., 2015). Compound 24 was tentatively identified as ethyl rosmarinate. The mass spectrum of 26 exhibited base peak at $\mathrm{m} / \mathrm{z} 207$, corresponding to dihydrosinapoyl moiety, which was formed by cleavage of the ester bond that resulted in loss of glucose (180 Da) (Tian et al., 2013; El-Sayed et al., 2017). Compound 26 was tentatively assigned as dihydrosinapic acid- $O$-glucoside.

Compound 34 (Rt - $16.6 \mathrm{~min}$, Table 2) exhibited UV maximum absorption at $328 \mathrm{~nm}$, characteristic of caffeic acid derivatives. The mass spectrum exhibited $[\mathrm{M}-\mathrm{H}]^{-}$at $\mathrm{m} / \mathrm{z} 521$ and base peak at $\mathrm{m} / \mathrm{z}, 179$ (deprotonated caffeic acid) (Liang et al., 2017; Yang et al., 2018, Borrás-Linares et al., 2014; Lee et al., 2017). This fragment ion was not observed in mass spectra of rosmarinic acid-3-O-glucoside (Yang et al., 2018, Borrás-Linares et al., 2014, Lee et al., 2017), but it was detected in rosmarinic acid, the second most common ester of caffeic acid in the plant kingdom (Lee et al., 2017; Hashem et al., 2019). The base peak at $\mathrm{m} / \mathrm{z} 179$ was formed by cleavage of the ester bond, which produced the loss of $342 \mathrm{Da}$, corresponding to the 3,4-dihydroxyphenyl-lactic moiety plus a glucose, probably attached at the $3^{\prime}-O$ position. Compound 34 was tentatively identified as rosmarinic acid-3'- $O$-glucoside.

Compound 23 (Rt - $8.5 \mathrm{~min}$ ) and 33 (Rt - $15.9 \mathrm{~min}$ ) exhibited UV maximum absorption at 266 and $355 \mathrm{~nm}$, characteristic of flavonols. The mass spectrum of compound 23 exhibited $[\mathrm{M}-\mathrm{H}+\mathrm{HCOOH}]^{-}$adduct ion at $\mathrm{m} / \mathrm{z}$ 523 and $[\mathrm{M}-\mathrm{H}]^{-}$at $\mathrm{m} / \mathrm{z} 477$ and was identified as quercetin glucuronide (23) (Soares et al., 2019). The mass spectrum of compound 33 exhibited $[\mathrm{M}-\mathrm{H}]^{-}$at $\mathrm{m} / z 579$ and base peak at $\mathrm{m} / \mathrm{z} 417$, produced by the loss of glucose moiety (162 Da) (Soares et al., 2019, Vukics and Guttman, 2010) and was identified as kaempferol-7-O-arabinosyl-3- $O$-glucoside. Compound 32 (Rt - $14.0 \mathrm{~min}$ ) exhibited UV maximum absorption at $290 \mathrm{~nm}$, characteristic of flavanonol. Its mass spectrum exhibited [M - H] $]^{-}$at $\mathrm{m} / \mathrm{z} 581$, a fragment ion at $\mathrm{m} / \mathrm{z} 419$, resulting from loss of glucose moiety (162 Da) and base peak at $\mathrm{m} / z 389$ (Pitura and Arntfield, 2019). Compound 32 was assigned as dihydrokaempferol-7- $O$-arabinosyl-3- $O$-glucoside.

\subsection{Compounds Detected by RPHPLC-ESI-MS/MS Analyses of Leaf and Stem Ethanolic Extracts}

Compounds 19, 25, 27 and 28 were detected in ethanolic extracts from leaves and stems (Table 2). The mass spectrum of 19, (Rt - $2.7 \mathrm{~min}$ ) exhibited $[\mathrm{M}-\mathrm{H}]^{-}$at $\mathrm{m} / \mathrm{z}, 341$, and base peak at $\mathrm{m} / \mathrm{z}, 179$ (deprotonated caffeic acid), produced by the loss of glucose moiety (162 Da) (Karar and Kuhnert, 2015; Liang et al., 2017). Compared with its elution order and MS/MS fragmentation pattern, compound 19 was assigned as caffeic acid glucoside. For compound 25 (Rt - $10.6 \mathrm{~min}$ ), the mass spectrum exhibited [M - H] $]^{-}$at $\mathrm{m} / z 401$ (Figure 2), and base peak at $m / z 269\left(\mathrm{C}_{13} \mathrm{H}_{17} \mathrm{O}_{6}\right)$, produced by the loss of arabinose moiety (132 Da). Benzyl alcohol-7-O-arabinosyl glucoside 25 was detected in Sanchezia nobilis (Ellah et al., 2014) and was identified based on literature data (Karar and Kuhnert, 2015).

Compounds 27 (Rt - $11.4 \mathrm{~min}$ ) and 28 (Rt - $11.8 \mathrm{~min}$ ) exhibited maximum UV absorption at $310 \mathrm{~nm}$, which is characteristic of coumaric acid derivatives. Mass spectrum of 27 exhibited $[\mathrm{M}-\mathrm{H}+\mathrm{HCOOH}]^{-}$adduct ion at $\mathrm{m} / \mathrm{z}$ 491, [M - H] ${ }^{-}$at $m / z 445$ and base peak at $\mathrm{m} / \mathrm{z} 293$, which correspond to sinapyl alcohol diacetate after the loss of galloyl moiety (152 Da). Compound 27 was tentatively identified as 4-O-galloyl-sinapyl alcohol diacetate based on literature data (Nićiforović et al. 2017, Tian et al., 2013). The mass spectrum of 28 exhibited $[\mathrm{M}-\mathrm{H}+$ $\mathrm{HCOOH}]^{-}$adduct ion at $\mathrm{m} / \mathrm{z} 431$ and $\left[\mathrm{M}-\mathrm{H}^{-}\right.$at $\mathrm{m} / \mathrm{z}$ 385. Based on literature data (Nićiforović et al., 2017; El-Sayed et al., 2017, Yang et al., 2018), compound 28 was identified as sinapic acid- $O$-glucoside. The mass spectrum of compounds 20,22, 24, 25 and 34 are shown on Figure 2. The proposed structures of compounds 20, 22, 24, 30 and 34 are shown on Figure 3. Further studies should be performed through the isolation of these compounds in order to confirm the identification by NMR methods. 


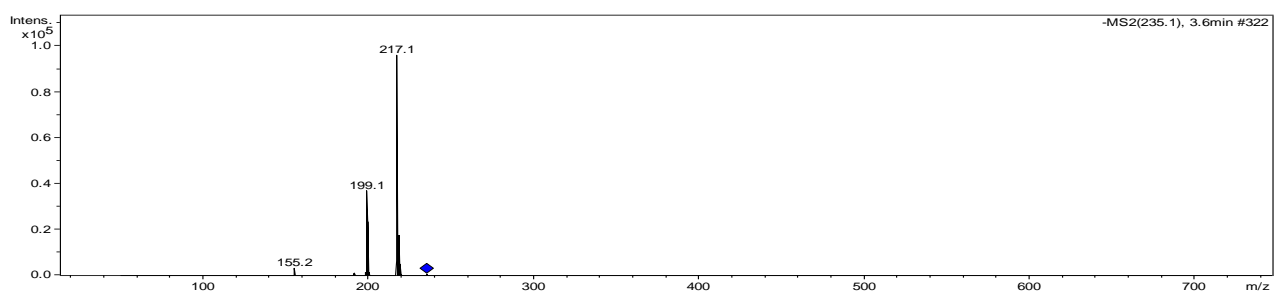

A

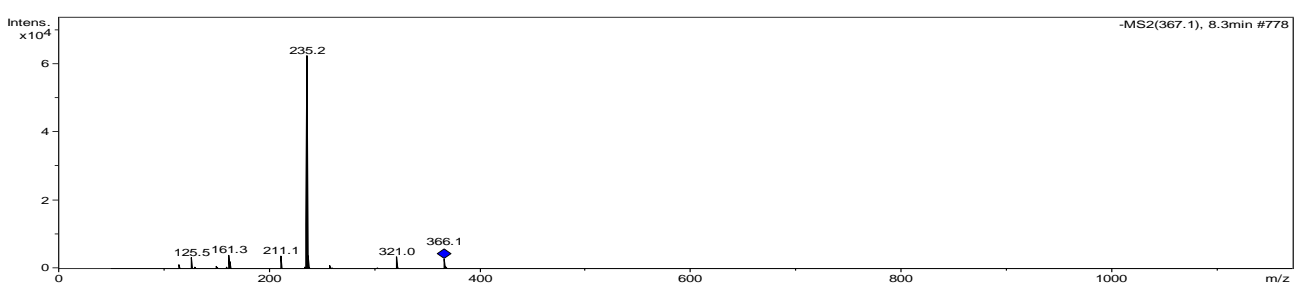

B
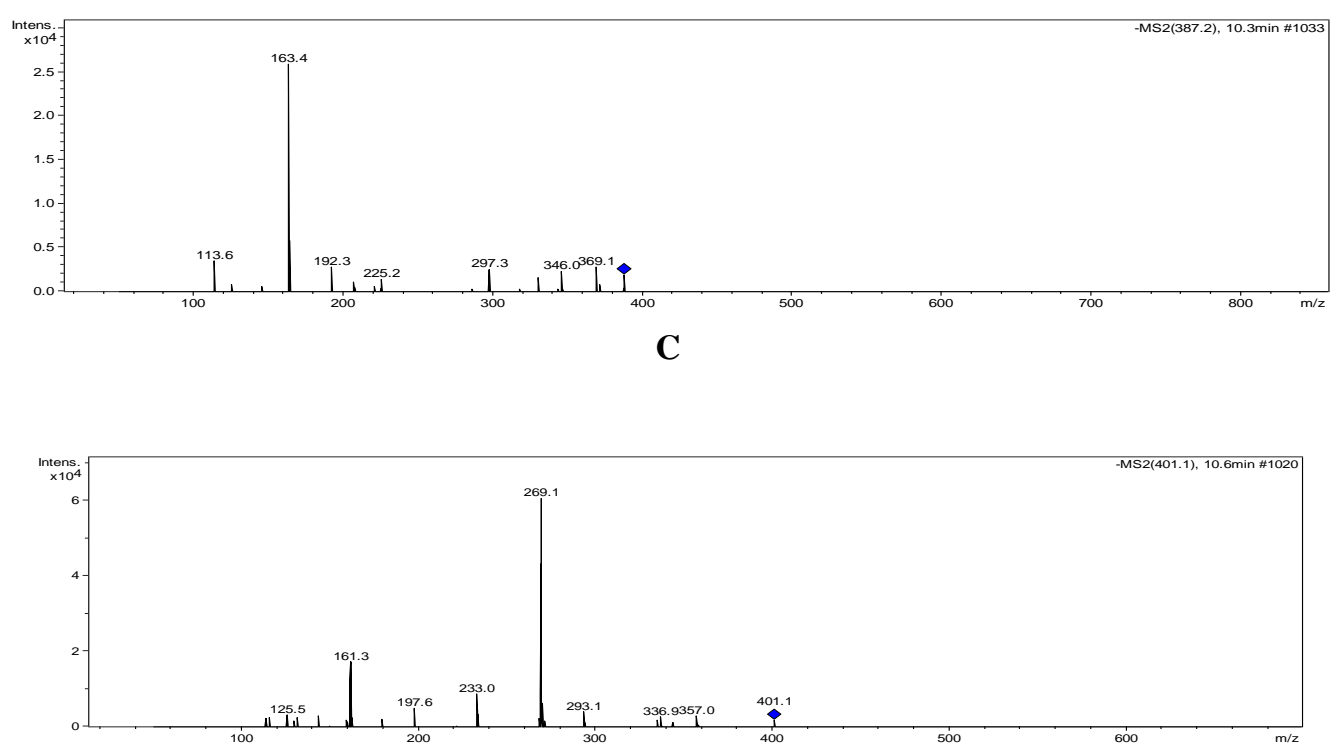

D

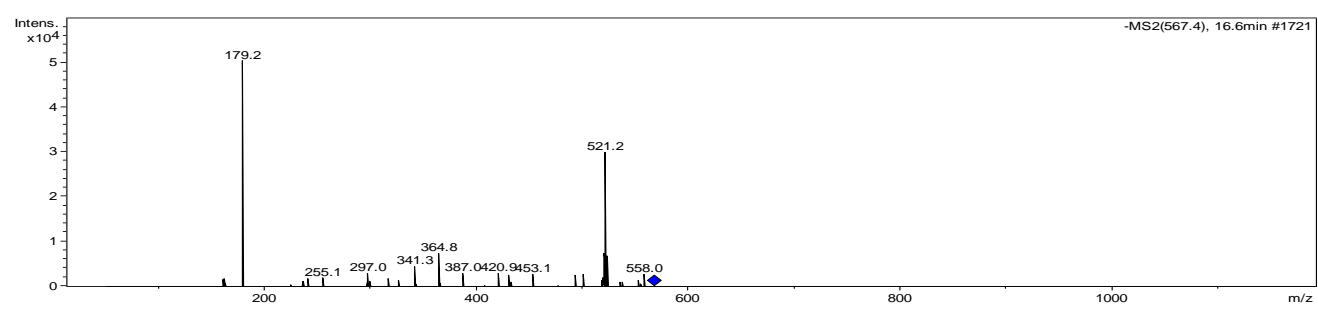

E

Figure 2. HPLC-ESI-MS/MS spectra in negative ion mode of compounds 20 (1- $O$-coumaroyl-2-hydroxy propanal; A), 22 (1-O-coumaroyl-2- $O$-arabinosyl propanal; B), 24 (ethyl rosmarinate; C), 25 (benzyl alcohol-7-O-arabinosyl glucoside; D) and 34 (rosmarinic acid-3'-O-glucoside; E) 
Table 2. Pseudomolecular ions and MS/MS fragment ions obtained for compounds 19-36 by RPHPLC-SPD-ESI-MS/MS analyses in negative ionization modes

\begin{tabular}{|c|c|c|c|c|c|c|c|}
\hline Cp.N ${ }^{a}$ & $\begin{array}{l}\mathbf{R t}^{\mathrm{b}} \\
(\mathrm{min})\end{array}$ & $\begin{array}{l}\text { UV } \\
(\mathbf{n m})\end{array}$ & $\begin{array}{l}\text { RPHPLC/(-)ESI- } \\
\text { MS/MS } m z(\%)\end{array}$ & $\begin{array}{l}\text { Proposed } \\
\text { Compound }^{\mathrm{c}}\end{array}$ & Refer. $^{d}$ & Stems $^{\mathrm{e}}$ & Leaves $^{f}$ \\
\hline 19 & 2.7 & 320 & $\begin{array}{l}{[\mathrm{M}-\mathrm{H}]^{-}: 341} \\
\text { MS/MS: } \\
179(100) \\
161(40), 143(40)\end{array}$ & $\begin{array}{l}\text { caffeic acid } \\
\text { glucoside }\end{array}$ & 32,43 & + & + \\
\hline 20 & 3.6 & 310 & $\begin{array}{l}{[\mathrm{M}-\mathrm{H}]: \text { : } 235} \\
\text { MS/MS: } 217(100), \\
199(50), 155(20)\end{array}$ & $\begin{array}{l}\text { 1-O-coumaroyl- } \\
\text { 2-hydroxy propanal }\end{array}$ & $19-24$ & - & + \\
\hline 21 & 6.1 & 254 & $\begin{array}{l}{[\mathrm{M}-\mathrm{H}]^{-}: 315} \\
\text { MS/MS: } 153\end{array}$ & $\begin{array}{l}\text { 4-Hydroxy- } \\
\text { 3-methoxybenzyl } \\
\text { alcohol glucoside }\end{array}$ & 34,35 & + & - \\
\hline 22 & 8.3 & 310 & $\begin{array}{l}{[\mathrm{M}-\mathrm{H}+\mathrm{HCOOH}]:} \\
413 ;[\mathrm{M}-\mathrm{H}]: 367 \\
\text { MS/MS: } 235\end{array}$ & $\begin{array}{l}\text { 1-O-coumaroyl- } \\
\text { 2-O-arabinosyl } \\
\text { propanal }\end{array}$ & $19-24$ & - & + \\
\hline 23 & 8.5 & $\begin{array}{l}260 \\
355\end{array}$ & $\begin{array}{l}{[\mathrm{M}-\mathrm{H}+\mathrm{HCOOH}]^{-}} \\
523 ;[\mathrm{M}-\mathrm{H}]: 477\end{array}$ & $\begin{array}{l}\text { Quercetin } \\
\text { glucuronide }\end{array}$ & 28 & + & - \\
\hline 24 & 10.3 & 320 & {$[\mathrm{M}-\mathrm{H}]: 387$} & Ethyl rosmarinate & $36-39$ & + & - \\
\hline 25 & 10.6 & 254 & $\begin{array}{l}{[\mathrm{M}-\mathrm{H}]=401} \\
\text { MS/MS: } 269\end{array}$ & $\begin{array}{l}\text { benzyl alcohol-7-O- } \\
\text { arabinosyl glucoside }\end{array}$ & 3,32 & + & + \\
\hline 26 & 11.0 & - & $\begin{array}{l}{[\mathrm{M}-\mathrm{H}]: 387} \\
\text { MS/MS: } 207(100)\end{array}$ & $\begin{array}{l}\text { dihydrosinapic acid- } \\
O \text {-glucoside }\end{array}$ & 41,42 & + & - \\
\hline 27 & 11.4 & 325 & $\begin{array}{l}{[\mathrm{M}-\mathrm{H}+\mathrm{HCOOH}]^{-}} \\
\text {491; [M-H] }: 445 \\
\text { MS/MS: } 293\end{array}$ & $\begin{array}{l}\text { 4-O-galloyl-sinapyl } \\
\text { alcohol diacetate }\end{array}$ & 26,41 & + & + \\
\hline 28 & 11.8 & 330 & $\begin{array}{l}{[\mathrm{M}-\mathrm{H}+\mathrm{HCOOH}]^{-}} \\
431 ;[\mathrm{M}-\mathrm{H}]: 385\end{array}$ & $\begin{array}{l}\text { sinapic acid- } O \text { - } \\
\text { glucoside }\end{array}$ & $26,42,44$ & + & + \\
\hline 29 & 12.8 & 318 & $\begin{array}{l}{[\mathrm{M}-\mathrm{H}+\mathrm{HCOOH}]:} \\
457 ;[\mathrm{M}-\mathrm{H}]: 411 \\
\text { MS/MS: } 279\end{array}$ & $\begin{array}{l}\text { 4- } O \text {-arabinosyl } \\
\text { butyl sinapate }\end{array}$ & $25-27$ & - & + \\
\hline 30 & 13.3 & 315 & $\begin{array}{l}{[\mathrm{M}-\mathrm{H}+\mathrm{HCOOH}]:} \\
427 ;[\mathrm{M}-\mathrm{H}]: 381 \\
\text { MS/MS: } 235\end{array}$ & $\begin{array}{l}\text { 1-O-coumaroyl-2-O-rhamnosyl } \\
\text { propanal }\end{array}$ & $19-24$ & - & + \\
\hline 31 & 13.5 & - & $\begin{array}{l}{[\mathrm{M}-\mathrm{H}+\mathrm{HCOOH}]^{-}} \\
461 ;[\mathrm{M}-\mathrm{H}]: 415\end{array}$ & $\begin{array}{l}\text { 4-O-glucosyl-ethyl- } \\
\text { dihydrosinapate }\end{array}$ & $25-27$ & - & + \\
\hline 32 & 14.0 & $\begin{array}{l}290 \\
330 \mathrm{sh}\end{array}$ & $\begin{array}{l}{[\mathrm{M}-\mathrm{H}]^{-}: 581} \\
\text { MS/MS: } 419(50), \\
389(100)\end{array}$ & $\begin{array}{l}\text { dihydrokaempferol- } \\
\text { 7-O-arabinosyl-3-O- } \\
\text { glucoside }\end{array}$ & 30 & + & - \\
\hline 33 & 15.9 & $\begin{array}{l}266 \\
348\end{array}$ & $\begin{array}{l}{[\mathrm{M}-\mathrm{H}]: 579} \\
\text { MS/MS: } 417\end{array}$ & $\begin{array}{l}\text { kaempferol-7-O- } \\
\text { arabinosyl-3-O- } \\
\text { glucoside }\end{array}$ & 28,29 & + & - \\
\hline 34 & 16.6 & 328 & $\begin{array}{l}{[\mathrm{M}-\mathrm{H}+\mathrm{HCOOH}]:} \\
567 ;[\mathrm{M}-\mathrm{H}]: 521 \\
\text { MS/MS: } 179\end{array}$ & $\begin{array}{l}\text { rosmarinic acid- } \\
\text { 3'- } O \text {-glucoside }\end{array}$ & $43-46$ & + & - \\
\hline 35 & 25.1 & $\begin{array}{l}266 \\
355\end{array}$ & $\begin{array}{l}{[\mathrm{M}-\mathrm{H}+\mathrm{HCOOH}]:} \\
493 ;[\mathrm{M}-\mathrm{H}]: 447\end{array}$ & kaempferol-7-O-glucoside & $28-30$ & - & + \\
\hline 36 & 26.5 & 280 & $\begin{array}{l}{[\mathrm{M}-\mathrm{H}]: 421} \\
\text { MS/MS: } 289\end{array}$ & catechin- $O$-arabinoside & $21,31-33$ & - & + \\
\hline
\end{tabular}

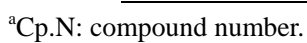

${ }^{\mathrm{b}} \mathrm{Rt}$ : retention time.

cidentified based on MS/MS and UV data and their comparison with MS/MS and other data from reference sources.

${ }^{\mathrm{d}}$ references used in identification (see text) 


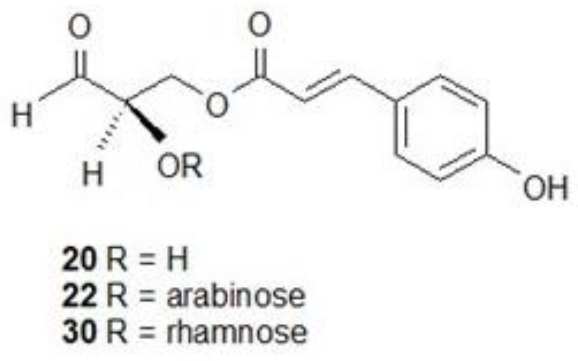<smiles>CCOC(=O)C(CC(=O)/C=C/c1ccc(O)c(O)c1)Cc1ccc(O)c(O)c1</smiles>

24<smiles>[R6]c1c(OC)cc(/C=C/C(=O)OCCCC)cc1OC</smiles>

$29 \mathrm{R}=$ arabinose<smiles>[R]Oc1cc(CC(OC(=O)/C=C/c2ccc(O)c(O)c2)C(=O)O)ccc1O</smiles>

$34 \mathrm{R}=$ glucose

Figure 3. Proposed structures for compounds 20, 22, 24, 29, 30 and 34

\section{Discussion}

Differences were observed comparing the distribution of constituents of leaves and stems extracts by GC-EI-MS (Table 1) and RPHPLC-DAD-ESI-MS/MS analyses (Table 2). In the analyses by GC-EI-MS (Table 1), the steroids 14-18 were found only in extract from stems. Other unique constituents of stem extracts were methyl salicylate (2) and 9,12-octadecadienal (8). Stigmasterol (15) and sitosterol (16) were detected in higher amounts (5.8\% and 4.8\%, respectively) than campesterol (14, 1.3\%), stigmasta-4,22-dien-3-one $(17,0.6 \%)$ and stigmasta-4-en-3-one (18, 0.9\%). 5-Methyl-4-hepten-3-one (3) was the main constituent of the ethanolic extract from stems $(31.1 \%)$ and was also detected with high content in leaf ethanolic extract (21.4\%, Table 1).

Regarding the RPHPLC-ESI-MS/MS analyses (Table 2), the new compounds, tentatively identified as phenylpropane glycerides derivatives (20, 22 and 30), sinapic acid glycoside esters (29 and 31), kaempferol-7-O-glucoside (35) and catechin- $O$-arabinoside (36) were detected only in ethanolic extract from leaves. Caffeic acid glucoside (19), benzyl alcohol-7-O-arabinosyl glucoside (25), 4-O-galloyl-sinapyl alcohol diacetate (27) and sinapic acid- $O$-glucoside (28) were detected in the two ethanolic extracts. On the other hand, 4-hydroxy-3-methoxybenzyl alcohol glucoside (21), ethyl rosmarinate (24), dihydrosinapic acid- $O$-glucoside (26), rosmarinic acid-3'-O-glucoside (34) and the flavonols glycosides 23, 32 and 33 were detected only in ethanolic extract from stems (Table 2). It is noteworthy that ethyl rosmarinate (24) and rosmarinic acid-3'-O-glucoside (34) were unique in the ethanolic extract of stems. Differences in gene expression between plant parts is well known. For example, plant polyphenol profile varied widely ontogenetically and among organs of Geranium sylvaticum (Tuominem and Salminem, 2017).

There have been few chemical studies about genus Sanchezia. In this study a hyphenated chromatographic analysis of ethanolic extracts of leaves and stems of S. oblonga was performed. Although the isolation of constituents is necessary for their identification by NMR methods, it is possible to observe that the results are different from those previously obtained for this species (Ellah et al., 2014). Table 2 lists various synapic acids and their esters, phenylpropane glycerides derivatives and rosmarinic acid derivatives, which had not been reported previously for this species. In this work, phytosterols and kaempferol glycosides were detected only in stems. However, a recent work reported that phytosterols were isolated from $n$-hexane and ethylacetate extract of the leaves (Xuan et al., 2019a,b, Loi et al., 2019a), while kaempferol glycosides were isolated from ethylacetate and aqueous extracts of leaves of S. nobilis (syn. S. oblonga) (Xuan et al., 2019b, Loi et al., 2019b).

The differences in chemical composition between the extracts analyzed in the present work and the previously published papers regarding S. nobilis can be explained by two possibilities: a) they may correspond to the same species but to different varieties or chemotypes; b) differences may be due to climate, season or growing 
conditions (Liu et al., 2015).

S. oblonga may turn out an interesting source of bioactive substances. Phytosterols exhibited antibacterial and antifungal activity (Aldini et al., 2014), are active against leukemic cell lines (Suttiarporn et al., 2015) and useful in the treatment of gastrointestinal inflammatory diseases by association with systemic and local metabolic anti-inflammatory drugs (Burčová et al., 2018). Stigmasterol inhibited tumor endothelial cells and cholangiocarcinoma (Saeidnia et al., 2014, Kangsamaksin et al., 2017). Sterols inhibited cholesterol absorption and exhibited trypanocidal and mosquito larvicidal activity (Ghosh et al., 2013). Hydroxycinnamic acids and their derivatives promote a variety of health benefits, e.g. reducing obesity and adverse health complications (Alam et al., 2016), as well as exhibiting antibacterial, antifungal (Guzman, 2014), antityrosinase, UV protection, anti-aging and anti-inflammatory effects (Alam et al., 2016).

Synapic acid derivatives exhibited antioxidant, antimicrobial, anti-inflammatory, anti-cancer, anti-anxiety (Nićiforović et al., 2017), anti-glycemic, neuroprotective, antibacterial (Chen, 2016) and analgesic activities (Hameed et al., 2016). Rosmarinic acid esters exhibited a broad spectrum of biological effects (Shen et al., 2018; Liang et al., 2017; Thammason et al., 2018). Glycerol phenylpropanoid glucosides act as hepatic glucose production inhibitors; structure-activity relationships indicated that the hydroxylation pattern of the hydroxycinnamic acid moiety and acetylation accounted for differences in activity (Murray et al., 2019).

\section{Conclusion}

Leaves and stems of Sanchezia oblonga contain a variety of biologically active compounds, such as phytosterols, flavonol glycosides, benzyl alcohol glycosides, sinapic acid glycoside esters, phenylpropane glycerides and rosmaric acid derivatives, which were detected using GC-EI-MS and RPHPLC-DAD-ESI-MS/MS. These techniques revealed that ethanolic extracts of leaves and stems contain distinct chemical profiles. The leaves contain phenylpropane glycerides and can be used in cooking as supplement. Comparison of the current results with previous studies suggests the possibility of chemical polymorphisms within species. Further studies are needed to explore this possibility. Compounds should be isolated and identified by NMR methods. Statistical methods, principal component analysis and hierarchical cluster analysis can be applied to evaluate intrinsic quality and identify chemical markers, which is useful for the chemical standardization of this species.

\section{Acknowledgments}

This investigation was partly funded by CNPq (Conselho Nacional do Desenvolvimento Científico e Tecnológico) and FAPESP (Fundação de Amparo à Pesquisa do Estado de São Paulo).

\section{Conflict of Interests}

We confirm that there is no conflict of interest associated with this work.

\section{References}

Abad-García, B., Berrueta, L. A., Garmón-Lobato, S., Gallo, B., \& Vicente, F. (2009). A general analytical strategy for the characterization of phenolic compounds in fruit juices by high-performance liquid chromatography with diode array detection coupled to electrospray ionization and triple quadrupole mass spectrometry. Journal of Chromatography A, 1216, 5398-5415.

https://doi.org/10.1016/j.chroma.2009.05.039

Alam, M. A., Subhan, N., Hossain, H., Hossain, M., Reza, H. M., Rahman, M.M., \& Ullah, M. O. (2016). Hydroxycinnamic acid derivatives: a potential class of natural compounds for the management of lipid metabolism and obesity. Nutrition \& Metabolism, 13, 27. https://doi.org/10.1186/s12986-016-0080-3

Aldini, R., Micucci, M., Cevenini, M., Fato, R., Bergamini, C., Nanni, C., ... Budriesi, R. (2014). Antiinflammatory effect of phytosterols in experimental murine colitis model: prevention, induction, remission study. PLoS One, 9, e108112. https://doi.org/10.1371/journal.pone.0108112

Aziz, S., Irshad, M., \& Habib-ur-Rehman. (2014). Isolation of a new antibacterial polyphenol from Thymus serpyllum. Chemistry of Natural Compounds, 49, 1023-1027. https://doi.org/10.1007/s10600-014-0814-2

Borrás-Linares, I., Stojanović, Z., Quirantes-Piné, R., Arráez-Román, D., Švarc-Gajić, J., Fernández-Gutiérrez, A., \& Segura-Carretero, A. (2014). Rosmarinus Officinalis Leaves as a Natural Source of Bioactive Compounds. International Journal Molecular Science, 15, 20585-20606. https://doi.org/10.3390/ijms151120585

Bui Thanh, T., Vu Duc, L., Nguyen Thanh, H., \& Nguyen Tien, V. (2017). In vitro antioxidant and anti-inflammatory activities of isolated compounds of ethanol extract from Sanchezia speciosa Leonard's 
leaves. Journal of Basic and Clinical Physiology and Pharmacology, 28, 79-84. https://doi.org/10.1515/jbcpp-2016-0086

Burcová, Z., Kreps, F., Greifová, M., Jablonský, M., Ház, A., Schmidt, Š., \& Šurina, I. (2018). Antibacterial and antifungal activity of phytosterols and methyl dehydroabietate of Norway spruce bark extracts. Journal Biotechnology, 282, 18-24. https://doi.org/10.1016/j.jbiotec.2018.06.340

Chen, Y-Z., Kao, S-Y., Jian, H-C., Yu, Y-M., Li, J-Y., Wang, W-H., \& Tsai, C-W. (2015). Determination of cholesterol and four phytosterols in foods without derivatization by gas chromatography-tandem mass spectrometry. Journal of Food and Drug Analysis, 23, 636-644. https://doi.org/10.1016/j.jfda.2015.01.010

Chen, C. (2016). Sinapic Acid and Its Derivatives as Medicine in Oxidative Stress-Induced Diseases and Aging. Oxidative Medicine and Cellular Longevity, Article ID 3571614. http://dx.doi.org/10.1155/2016/3571614

Coelho, G. R., Figueiredo, C. A., Negri, G., Fernandes-Silva, C. C., Villar, K. S., Badari, J. C., ... Mendonça, R. Z. (2018). Antiviral Activity of Geopropolis Extract from Scaptotrigona Aff. Postica against Rubella Virus. Journal of Food Research, 7(6). https://doi.org/10.5539/jfr.v7n6p91

Ellah, A. E. A., Mohamed, K. M., Backheet, E.Y., \& Mohamed M. H. (2013). Matsutake alcohol glycosides from Sanchezia nobilis. Chemistry of Natural Compounds, 48, 930-933. https://doi.org/10.1007/s10600-013-0431-5

Ellah, A. E. A., Mohamed, K. M., Backheet, E. Y., \& Mohamed, M. H. (2014). Cinnamyl Alcohol, Benzyl Alcohol, and Flavonoid Glycosides from Sanchezia nobilis. Chemistry of Natural Compounds, 50, 823-826. https://doi.org/10.1007/s10600-014-1092-8

El-Sayed, M. A., Al-Gendy, A. A., Hamdan, D. I., \& El-Shazly, A. M. (2017). Phytoconstituents, LC-ESI-MS profile, antioxidant and antimicrobial activities of citrus X limon L. Burm. F. cultivar variegated pink lemon. Journal of Pharmaceutical Sciences and Research, 9, 375-391.

Falção, S. I., Vale, N., Gomes, P., Domingues, M. R., Freire, C., Cardoso, S. M., \& Vilas-Boas, M. (2013). Phenolic profiling of Portuguese propolis by LC-MS spectrometry: uncommon propolis rich in flavonoid glycosides. Phytochemical Analysis, 24, 309-318. https://doi.org/10.1002/pca.2412

Ghosh, A. (2013). Efficacy of phytosterol as mosquito larvicide. Asian Pacific Journal of Tropical Disease, 3 , 252. https://doi.org/10.1016/S2222-1808(13)60050-X

Guzman, J. D. (2014). Natural Cinnamic Acids, Synthetic Derivatives and Hybrids with Antimicrobial Activity. Molecules, 19, 19292-19349. https://doi.org/10.3390/molecules191219292

Hameed, H., Aydin, S., \& Başaran, N. (2016). Sinapic acid: is it safe for humans? FABAD Journal of Pharmaceutical Science, 41, 39-49.

Hashem, M. M., Salama, M. M., Mohammed, F. F., Tohamy, A. F., \& El Deeb, K. S. (2019). Metabolic profile and hepatoprotective effect of Aeschynomene elaphroxylon (Guill. \& Perr.). PLoS ONE, 14, e0210576. https://doi.org/10.1371/journal.pone.0210576

Hong, E., \& Kim, G-H. (2013). GC-MS Analysis of the Extracts from Korean Cabbage (Brassica campestris L. ssp. pekinensis) and Its Seed. Preventive Nutrition and Food Science, 18, 218-221. https://doi.org/10.3746/pnf.2013.18.3.218

Jayasekara, T. K., Stevenson, P. C., Belmain, S. R., Farman, D. I., \& Hall, D. R. (2002). Identification of methyl salicylate as the principal volatile component in the methanol extract of root bark of Securidaca longepedunculata Fers. Journal Mass Spectrometry, 37, 577-580. https://doi.org/10.1002/jms.314

Kadam, D., Palamthodi, S., \& Lele, S. S. (2018). LC-ESI-Q-TOF-MS/MS profiling and antioxidant activity of phenolics from L. Sativum seedcake. Journal of Food Science and Technology, 55, 1154-1163. https://doi.org/10.1007/s13197-017-3031-8

Kang, J., Price, W. E., Ashton, J., Tapsell, L. C., \& Johnson, S. (2016). Identification and characterization of phenolic compounds in hydromethanolic extracts of sorghum wholegrains by LC-ESI-MS(n). Food Chemistry, 211, 215-226. https://doi.org/10.1016/j.foodchem.2016.05.052

Kangsamaksin, T., Chaithongyot, S., Wootthichairangsan, C., Hanchaina, R., Tangshewinsirikul, C., \& Svasti, J. (2017). Lupeol and stigmasterol suppress tumor angiogenesis and inhibit cholangiocarcinoma growth in mice via downregulation of tumor necrosis factor- $\alpha$. PLOS ONE, 12, e0189628.

https://doi.org/10.1371/journal.pone.0189628 
Karar, M. G. E., \& Kuhnert, N. (2015). UPLC-ESI-Q-TOF-MS/MS Characterization of Phenolics from Crataegus monogyna and Crataegus laevigata (Hawthorn) Leaves, Fruits and their Herbal Derived Drops (Crataegutt Tropfen). Journal of Chemical Biology \& Therapeutics, 1, 102.

Koo, I., Kim, S., \& Zhang, X. (2013). Comparative analysis of mass spectral matching-based compound identification in gas chromatography-mass spectrometry. Journal of Chromatography A, 1298, 132-138. https://doi.org/10.1016/j.chroma.2013.05.021

Kumar, R. B. (2017). Application of HPLC and ESI-MS techniques in the analysis of phenolic acids and flavonoids from green leafy vegetables (GLVs). Journal Pharmaceutical Analysis, 7, 349-364. https://doi.org/10.1016/j.jpha.2017.06.005

Lee, Y. H., Kim, B., Kim, S., Kim, M. S., Kim, H., Hwang, S. R., Kim, K., \& Lee, J. H. (2017). Characterization of metabolite profiles from the leaves of green perilla (Perilla frutescens) by ultra high performance liquid chromatography coupled with electrospray ionization quadrupole time-of-flight mass spectrometry and screening for their antioxidant properties. Journal of Food and Drug Analysis, 25, 776-788. https://doi.org/10.1016/j.jfda.2016.09.003

Leonard, E. C., \& Smith, L. B. (1964). Sanchezia and related American Acanthaceae. Rhodora, 66, 313-343. Retrieved from www.jstor.org/stable/23308424

Liang, W., Chen, W., Wu, L., Li, S., Qi, Q., Cui, Y., Liang, L., Ting, Y. T., \& Zhang, L. (2017). Quality Evaluation and Chemical Markers Screening of Salvia miltiorrhiza Bge. (Danshen) Based on HPLC Fingerprints and HPLC-MS ${ }^{\mathrm{n}}$ Coupled with Chemometrics. Molecules, 22, 478. https://doi.org/10.3390/molecules22030478

Liu, W., Liu, J., Yin, D., \& Zhao, X. (2015). Influence of ecological factors on the production of active substances in the anti-cancer plant Sinopodophyllum hexandrum (Royle) T.S. Ying. PLoS One, 10, e0122981. https://doi.org/10.1371/journal.pone.0122981

Loi, V. D., Xuan B. T., \& Ngoc T. M. (2019a). Chemical constituents and anti-ulcer activity of ethylacetate extract of the leaves of Sanchezia nobilis Hook. F. Pharmacognosy Journal, 11, 1172-1180. https://doi.org/10.5530/pj.2019.11.182

Loi, V. D., Xuan B. T., \& Ngoc T. M. (2019b). Chemical constituents and antacid activity of aqueous extract of the leaves of Sanchezia nobilis Hook. F. from Vietnam. Research \& Reviews: A Journal of Pharmacognosy, $6,15-22$.

Martinović, N., Ulrih, N. P., \& Abramovič, H. (2019). Sinapic acid and its derivatives increase oxidative stability in different model lipid systems: Effect of sinapic acid derivatives on lipid peroxidation. European Journal of Lipid Science and Technology, 121, Article 1800326. https://doi.org/10.1002/ejlt.201800326

Monção, N. B., Araújo, B. Q., Silva, J. N., Lima, D. J., Ferreira, P. M., Airoldi, F. P., Pessoa, C., \& Citó, A. M. (2015). Assessing chemical constituents of Mimosa caesalpiniifolia stem bark: possible bioactive components accountable for the cytotoxic effect of $M$. caesalpiniifolia on human tumour cell lines. Molecules, 20, 4204-4224. https://doi.org/10.3390/molecules20034204

Munafo Jr, J. P., \& Gianfagna, T. J. (2015). Quantitative analysis of phenylpropanoid glycerol glucosides in different organs of Easter Lily (Lilium longiflorum Thunb.) Journal of Agricultural and Food Chemistry, 63, 4836-4842. https://doi.org/10.1021/acs.jafc.5b00893

Murray, A. F., Palatini, K., Komarnytsky, S., Gianfagna, T. J., \& Munafo Jr, J. P. (2019). Phenylpropanoid glycerol glucosides attenuate glucose production in hepatocytes. ACS Omega, 4, 10670-10676. https://doi.org/10.1021/acsomega.9b00751

Negri, G., Barreto, L. M. R. C., Sper F. L., de Carvalho C, \& Rodrigues Campos, M.G. (2018). Phytochemical analysis and botanical origin of Apis mellifera bee pollen from the municipality of Canavieiras, Bahia State, Brazil. Brazilian Journal of Food Technology, 21, e2016176. http://dx.doi.org/10.1590/1981-6723.17616

Nguyen, P. H., Zhao, B. T., Lee, J. H., Kim, Y. H., Min, B. S., \& Woo. M. H. (2015). Isolation of benzoic and cinnamic acid derivatives from the grains of Sorghum bicolor and their inhibition of lipopolysaccharide-induced nitric oxide production in RAW 264.7 cells. Food Chemistry, 168, 512-519. https://doi.org/10.1016/j.foodchem.2014.06.119

Nićiforović, N., Polak, T., Makuc, D., Poklar Ulrih, N., \& Abramovič, H. (2017). A Kinetic Approach in the Evaluation of Radical-Scavenging Efficiency of Sinapic Acid and Its Derivatives. Molecules, 22, pii: E375. 
https://doi.org/10.3390/molecules22030375

Olvera-Garcia, V., Martin Del Campo, S. T., Gutierrez-Uribe, J. A., \& Cardador-Martinez, A. (2015). GC-MS and HPLC-MS-TOF characterization of Agave atrovirens extracts. A preliminary study. Industrial Crops and Products, 78, 39-47. https://doi.org/10.1016/j.indcrop.2015.09.068

Parvin, S., Rafshanjani, M. A. S., Kader, M. A., \& Sharmin, T. (2015). Preliminary phytochemical screening and cytotoxic potentials from leaves of Sanchezia speciosa Hook. F. International Journal of Advances in Scientific Research, 1, 145-150. https://doi.org/10.7439/ijasr.v1i3.1842

Pitura, K., \& Arntfield, S. D. (2019). Characteristics of flavonol glycosides in bean (Phaseolus vulgaris L.) seed coats. Food Chemistry, 272, 26-32. https://doi.org/10.1016/j.foodchem.2018.07.220

Saeidnia, S., Manayi, A., Gohari, A. R., \& Abdollahi, M. (2014). The Story of Beta-sitosterol- A Review. European Journal of Medicinal Plants, 4, 590-609. https://doi.org/10.9734/EJMP/2014/7764

Salazar-López, N. J., González-Aguilar, G., Rouzaud-Sández, O., \& Maribel Robles-Sánchez, M. (2018). Technologies applied to sorghum (Sorghum bicolor L. Moench): changes in phenolic compounds and antioxidant capacity. Food Science and Technology, 38, 369-382. https://doi.org/10.1590/fst.16017

Shaheen, N., Uzair, M., Ahmad, B., \& Alamgeer. (2017). In vitro cytotoxicity of sanchezia speciosa extracts on human epithelial cervical cancer (hela) cell line. Acta Poloniae Pharmaceutica - Drug Research, 74, 1389-1394.

Shen , Y. H., Wang, L. Y., Zhang, B. B., Hu, Q. M., Wang, P., He, B. Q., Bao, G. H., Liang, J. Y., \& Wu, F. H. (2018). Ethyl Rosmarinate Protects High Glucose-Induced Injury in Human Endothelial Cells. Molecules, 23, pii: E3372. https://doi.org/10.3390/molecules23123372

Soares, J. C., Rosalen, P. L., Lazarini, J. G., Massarioli, A. P., da Silva, C. F., Nani, B. D., Franchin, M., \& de Alencar, S.M. (2019). Comprehensive characterization of bioactive phenols from new Brazilian superfruits by LC-ESI-QTOF-MS, and their ROS and RNS scavenging effects and anti-inflammatory activity. Food Chemistry, 281, 178-188. https://doi.org/10.1016/j.foodchem.2018.12.106

Sudha, T., Chidambarampillai, S., \& Mohan, V. R. (2013). GC-MS Analysis of Bioactive Components of Aerial parts of Fluggea leucopyrus Willd. (Euphorbiaceae). Journal of Applied Pharmaceutical Science, 3, 126-130.

Suttiarporn, P., Chumpolsri, W., Mahatheeranont, S., Luangkamin, S., Teepsawang, S., \& Leardkamolkarn, V. (2015). Structures of Phytosterols and Triterpenoids with Potential Anti-Cancer Activity in Bran of Black Non-Glutinous Rice. Nutrients, 7, 1672-1687. https://doi.org/10.3390/nu7031672

Svensson, L., Sekwati-Monang, B., Lutz, D. L., Schieber, A., \& Ganzle, M. G. (2010). Phenolic Acids and Flavonoids in Nonfermented and Fermented Red Sorghum (Sorghum bicolor (L.) Moench). Journal of Agricultural and Food Chemistry, 58, 9214-9220. https://doi.org/10.1021/jf101504v

Taofiq, O., González-Paramás, A. M., Barreiro, M. F., \& Ferreira, I. C. F. R. (2017). Hydroxycinnamic Acids and Their Derivatives: Cosmeceutical Significance, Challenges and Future Perspectives, a Review. Molecules, 22, 281. https://doi.org/10.3390/molecules22020281

Teixeira, J., Gaspar, A., Garrido, E. M., Garrido, J., \& Borges, F. (2013). Hydroxycinnamic Acid Antioxidants: An Electrochemical Overview. BioMed Research International, Article ID 251754. http://dx.doi.org/10.1155/2013/251754

Thammason, H., Khetkam, P., Pabuprapap, W., Suksamrarn, A., \& Kunthalert, D. (2018). Ethyl rosmarinate inhibits lipopolysaccharide-induced nitric oxide and prostaglandin $\mathrm{E}_{2}$ production in alveolar macrophages. European Journal of Pharmacology, 824, 17-23. https://doi.org/10.1016/j.ejphar.2018.01.042

Tian, X., Ding, G., Peng, C., Hu, Y., Li, L, Chen H, \& Zou Z. 2013. Sinapyl Alcohol Derivatives from the Lipo-soluble Part of Dichrocephala benthamii C. B. Clarke. Molecules, 18, 1720-1727. https://doi.org/10.3390/molecules 18021720

Tripp, E. A., \& Koenemann, D. M. (2015). Nomenclatural Synopsis of Sanchezia (Acanthaceae), Fifty Years Since Last Treated. Novon: A Journal for Botanical Nomenclature, 24, 213-221. https://doi.org/10.3417/2011050

Tuominem, A., \& Salminem, J. P. (2017). Hydrolyzable Tannins, Flavonol Glycosides, and Phenolic Acids Show Seasonal and Ontogenic Variation in Geranium sylvaticum. Journal of Agricultural and Food Chemistry, 65, 6387-6403. https://doi.org/10.1021/acs.jafc.7b00918 
Veličković, D., Dimitrijević, A., Bihelović, F., Bezbradica, D., Knežević-Jugović, Z., \& Milosavić, N. (2012). Novel glycoside of vanillyl alcohol, 4-hydroxy-3-methoxybenzyl- $\alpha$-D-glucopyranoside: study of enzymatic synthesis, in vitro digestion and antioxidant activity. Bioprocess and Biosystems Engineering, 35, 107-15. https://doi.org/10.1007/s00449-012-0695-3

Vukics, V., \& Guttman, A. (2010). Structural characterization of flavonoid glycosides by multi-stage mass spectrometry. Mass Spectrometry Reviews, 29, 1-16. https://doi.org/10.1002/chin.201028275

Wicha, P., Tocharus, J., Nakaew, A., Pantan, R., Suksamrarn, A., \& Tocharus, C. (2015). Ethyl rosmarinate relaxes rat aorta by an endothelium-independent pathway. European Journal of Pharmacology, 766, 9-15. https://doi.org/10.1016/j.ejphar.2015.09.003

Wu, G., Johnson, S. K., Bornman, J. F., Bennett, S. J., Clarke, M. W., Singh, V., \& Fang, Z. (2016). Growth temperature and genotype both play important roles in sorghum grain phenolic composition. Scientific Reports, 6, 21835. https://doi.org/10.1038/srep21835

Xuan, B. T., Loi, V. D., Ngoc, T. M., \& Dung, B. T. K. (2019b). Compounds Isolated from the Leaf of Sanchezia Nobilis Hook.f.. VNU Journal of Science: Medical and Pharmaceutical Sciences, 35, 61-66. https://doi.org/10.25073/2588-1132/vnumps.4146

Xuan, B. T., Loi, V. D., Thanh, T. B., \& Ngoc, T. M. (2019a). Chemical Constituents and Antiulcer Activity of n-Hexane Extract of Sanchezia nobilis Hook F. Leaves from Vietnam. Asian Journal of Chemistry, 31, 2125-2132. https://doi.org/10.14233/ajchem.2019.22156

Yang, Y., Ying, S., Li, T., Zhen, J., Chen, D., \& Wang, J. (2018). A sensitive LC-MS/MS-based bioanalytical method for quantification of salviaflaside and rosmarinic acid in rat plasma and its application in a pharmacokinetic study. Biomedical Chromatography, 32, e4259. https://doi.org/10.1002/bmc.4259

Zerbib, M., Mazauric, J. P., Meudec, E., Le Guernevé, C., Lepak, A., Nidetzky, B., Cheynier, V., Terrier, N., \& Saucier. C. (2018). New flavanol O-glycosides in grape and wine. Food Chemistry, 266, 441-448. https://doi.org/10.1016/j.foodchem.2018.06.019

\section{Copyrights}

Copyright for this article is retained by the author(s), with first publication rights granted to the journal.

This is an open-access article distributed under the terms and conditions of the Creative Commons Attribution license (http://creativecommons.org/licenses/by/4.0/). 